\title{
Article \\ The Effect of Farmyard Manure and Mineral Fertilizers on Sugar Beet Beetroot and Top Yield and Soil Chemical Parameters
}

\author{
Lukáš Hlisnikovský *, Ladislav Menšík $\mathbb{D}$, Kateřina Křížová and Eva Kunzová \\ Crop Research Institute in Prague, Drnovská 507/73, Prague 6-Ruzyně, 16106 Prague, Czech Republic; \\ ladislav.mensik@vurv.cz (L.M.); krizovak@vurv.cz (K.K.); kunzova@vurv.cz (E.K.) \\ * Correspondence: 1.hlisnik@vurv.cz; Tel.: +420-773-636-546
}

Citation: Hlisnikovský, L.; Menšík,

L.; Kř́ízová, K.; Kunzová, E. The

Effect of Farmyard Manure and

Mineral Fertilizers on Sugar Beet Beetroot and Top Yield and Soil Chemical Parameters. Agronomy 2021, 11, 133. https://doi.org/10.3390/ agronomy11010133

Received: 14 December 2020 Accepted: 8 January 2021 Published: 12 January 2021

Publisher's Note: MDPI stays neutral with regard to jurisdictional clai$\mathrm{ms}$ in published maps and institutional affiliations.

Copyright: (C) 2021 by the authors. Licensee MDPI, Basel, Switzerland. This article is an open access article distributed under the terms and conditions of the Creative Commons Attribution (CC BY) license (https:// creativecommons.org/licenses/by/ $4.0 /)$.

\begin{abstract}
In order to recommend the dose of fertilization for sugar beet under currently unstable weather conditions, we analysed beetroot and top yields, sugar content (SC), and the effect of fertilization on soil chemistry over a three-year period (2016-2018). All three years were characterized by different weather conditions. The year 2016 was very warm and very dry. The year 2017 was warm with normal precipitation. The year 2018 was extraordinary warm and very dry. We compared the following ten fertilization treatments: unfertilized control, farmyard manure (FYM), mineral fertilizers NPK1-4, and FYM + NPK1-4. The applications of FYM, NPK, and FYM + NPK resulted in significantly higher yields of beetroots and tops as compared with the control, while no significant differences were recorded among FYM, NPK, and FYM + NPK treatments. The SC was not affected by the fertilization. The application of NPK resulted in a lower $\mathrm{pH}$ value, while the highest values were recorded for the control and FYM treatments. The application of FYM + NPK increased the content of organic carbon (Corg) in the soil, the total content of nitrogen (Ntot), and P and K concentrations. According to the results of the linear-plateau model, the recommended dose of $\mathrm{N}$ is $112 \mathrm{~kg} \mathrm{ha}^{-1}$, corresponding to a beetroot yield of $66 \mathrm{t} \mathrm{ha}^{-1}$.
\end{abstract}

Keywords: Beta vulgaris L.; organic manure; weather conditions; soil chemistry; sugar concentration

\section{Introduction}

Sugar beet is one of the most important crops in the EU, as it is the only raw material for sugar extraction. Sugar beet acts as a good breaker of cereal crop rotations in the field and is also a good pre-crop for cereals (except for spring barley [1]), which are the most abundant arable crops in the EU. During most of the 20th century, sugar beet was a strategic crop in the Czech Republic. With the change from a centrally planned economy to a market economy in 1989, followed by the application of EU quotas restricting beetroot yields, sugar beet has undergone significant changes both in regards to the size of sown areas and in yields per hectare. Today, sugar beet is grown on an average area of 61,000 ha in the Czech Republic.

Beetroot and top yield and the quality of sugar beet are affected by a wide range of factors. Some of these factors are controllable by the farmers, such as crop rotation [2], tillage practices [3-6], or fertilization, however, some of them are not, such as weather conditions [7]. Fertilization represents a crucial factor influencing the final yield and quality, especially fertilization with nitrogen $(\mathrm{N})$. The under application of $\mathrm{N}$ leads to a lower yield of beetroots and lower sucrose yield, while an over-application of $\mathrm{N}$ leads to imbalanced partitioning of assimilates, decreased sucrose content, and increased concentrations of impurities, resulting in reduced sucrose extraction [3,8-12] due to higher water retention by the beetroots and a lower amount of dry matter. An over-application of $\mathrm{N}$ also increases the concentration of soluble $\mathrm{N}$ compounds in the beetroots and this prevents subsequent extraction of sugar.

The determination of the optimal nitrogen dose varies from site to site, and therefore is site-specific dose. According to Chatterjee et al. [12], a single dose of $146 \mathrm{~kg} \mathrm{ha}^{-1}$ of N 
was recommended in North Dakota and Minnesota for sugar beet, irrespective of soil type and soil organic matter content, but this recommendation should be lowered to $112 \mathrm{~kg} \mathrm{ha}^{-1}$ of $\mathrm{N}$, based on their two years of research. According toDeBruyn et al. [13], a dose of $157 \mathrm{~kg} \mathrm{ha}^{-1}$ of $\mathrm{N}$ was associated with the highest beetroot yield, while $136 \mathrm{~kg} \mathrm{ha}^{-1}$ of $\mathrm{N}$ was associated with the highest profit, in their three year experiment in Canada. In Europe, much attention is being paid to sugar beet nutrition experiments. Islamgulov et al. [14] experimented with the hybrid Hercules and found that $160 \mathrm{~kg} \mathrm{ha}^{-1}$ of $\mathrm{N}$ provided the highest economic efficiency under the conditions of the middle Cis-Ural region. According to Malnou et al. [15], who analysed the response of sugar beet to $\mathrm{N}$ fertilization at five sites within the UK, a dose of $100 \mathrm{~kg}$ of $\mathrm{N}$ per ha, in the absence of organic manure, should be applied for maximum yield. Similar results $\left(100-110 \mathrm{~kg} \mathrm{ha}^{-1}\right.$ of N) were published by Jaggard et al. [16], who analysed 161 experiments from England in their meta-analysis. The optimal dose can be determined by modelling. There are several models applicable depending on the crop evaluated, the data obtained, and the answer to the question being asked [17]. The quadratic model offers an answer to the maximum yield depending on the dose of nutrients. This model is very suitable for winter wheat because, with an increasing dose of nitrogen, wheat yields initially increase and begin to decline after reaching a critical value [18]. However, determining the dose of nutrients, in this way, may not be statistically significantly different from the lower dose of applied nutrients. Not every crop follows a parabolic course for the dependence of yields and doses of applied nutrients. For example, the reaction of sugar beet yields on doses of nitrogen may be linear [19], even the differences between the analysed fertilizer treatments are not significant. In that case, a linear-plateau model can provide useable answers $[12,17,19]$.

Previously, the sugar beet crop, in the Czech Republic, was commonly fertilized with organic manures. We deliberately state "previously", because today's situation is completely different. There is a shortage of organic manure due to a reduction in animal production and there has been a significant split between animal and plant production, manifested by an insufficient amount of organic matter incorporated into the soil. The common doses of farmyard manure applied directly to potatoes and sugar beet range from 20 to 40 tons per hectare in the Czech Republic. As compared with mineral fertilizers, the content of nutrients in organic manures is non-standardized. Thus, the nutrient content may vary, depending on the animals from which it came, their diet, and other aspects. The mineralization process is also strongly dependent on weather conditions [20], and therefore farmers may not know exactly how much nutrients they applied to the soil, which may explain the recommendation to not use farmyard manure for sugar beet fertilization [21,22]. However, rising prices for mineral fertilizers [21] and the practice of growing sugar beet for the organic market [23] have increased the interest in the application of organic manures to sugar beet, especially in the USA, because the application of manures directly to sugar beet has a long tradition in Europe. Organic manures work in two ways. The first way represents direct releasing of nutrients into the soil environment through the process of mineralization. The second way represents the beneficial influence on the soil's physical, chemical, and biological properties [24-29], especially maintaining and increasing soil organic carbon (SOC) content. This indirect positive effect of livestock manure on crop yields was evidenced by Hlisnikovský et al. [18].

Concerning the issues discussed above, we analysed a three-year sequence in a longterm field experiment, and focused on how mineral fertilizers (different doses, NPK1-4), farmyard manure (FYM), and combinations of FYM and NPK (FYM + NPK1-4) affected the yield and quality of sugar beet beetroots and tops. In this paper, we also recommend the dose of fertilizers according to the linear-plateau regression model. The evaluation included three years $(2016,2017$, and 2018). All three years were characterized by different weather conditions. The year 2016 was very warm and very dry, but with relatively good conditions for sugar beet. The year 2017 was warm, with normal precipitation. The year 2018 was extraordinary warm and very dry, significantly affecting sugar beet beetroot and top yields, therefore, in our experiment, we covered the unfavourable conditions 
that occurred more frequently and were connected with global weather change. Finally, an analysis of soil properties affected by the fertilizer treatments is also provided.

\section{Materials and Methods}

\subsection{Site Description}

The long-term field trial was located on the western border of the city of Prague (the Czech Republic, Central Europe, temperate climate zone, $50^{\circ} 05^{\prime} 15^{\prime \prime} \mathrm{N}, 14^{\circ} 17^{\prime} 28^{\prime \prime} \mathrm{E}$ ). The trial was established to study the effect of different fertilizer treatments and crop rotations on yield and quality of arable crops and soil chemical properties. The year the trial was established was 1954. The annual mean precipitation and mean temperature from the establishment of the trial is shown in Figure 1. The standard climatological long-term average (1954-2019) precipitation and temperature was $490.4 \mathrm{~mm}$ and $8.65^{\circ} \mathrm{C}$, respectively. The standard climatological normal (1961-1990) of the precipitation and temperature was $472.8 \mathrm{~mm}$ and $7.97^{\circ} \mathrm{C}$, respectively. The average annual precipitation for the years 2016, 2017, and 2018 was 382.1, 470.0, and $345.3 \mathrm{~mm}$, respectively. The average annual temperature for the same years was $10.0,9.9$, and $11.1^{\circ} \mathrm{C}$, respectively. The average temperature at the site had an increasing trend, and total precipitation also increased slightly (Figure 1). According to Kožnarová and Klabzuba [30], all three years were characterized by different weather conditions. The year 2016 was very warm and very dry, with conditions relatively good for sugar beet. The year 2017 was warm with normal precipitation, providing optimal conditions for sugar beet. The year 2018 was extraordinary warm and very dry, significantly reducing beetroot and top yields. The altitude of the trial site is $370 \mathrm{~m}$ a.s.l. According to the World Reference Base [31], the soil type is haplic Luvisol.

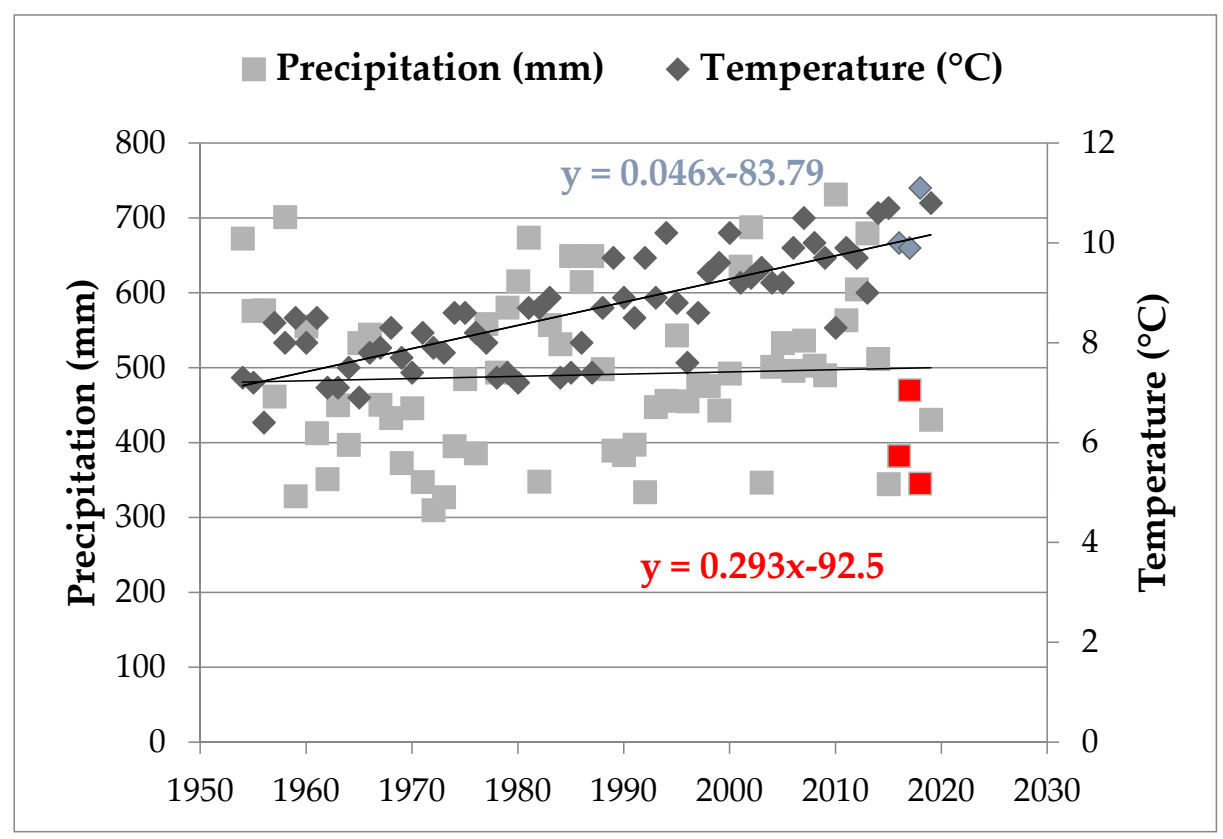

Figure 1. The mean annual precipitation $(\mathrm{mm})$ and temperature $\left({ }^{\circ} \mathrm{C}\right)$ at the experimental site in Prague (1954-2019). Blue and red squares indicate analysed years, blue is the linear regression equation for temperature and red is thelinear regression equation for precipitation.

\subsection{Experimental Design Description}

The long-term field trial consisted of five fields, marked as I, II, III, IV, and B. Each field consisted of 96 experimental plots $(12 \times 12 \mathrm{~m})$, where 24 different fertilizer treatments were applied in four replications $(24 \times 4=96)$. Each field was arranged in a completely randomized block design. The results used, in this paper, analysed the yield and quality of sugar beet from fields IV (2016), III (2017), and II (2018). The crop rotation in these fields 
was equal, consisting of red clover, red clover, winter wheat, sugar beet, spring barley, potatoes, winter wheat, sugar beet, and spring barley. In this paper, we analysed the sugar beet following the red clover-winter wheat sequence.Among the 24 fertilizer treatments, the following 10 fertilizer treatments were analysed in this paper: (1) the control (unfertilized since 1954), (2) NPK1, (3) NPK2, (4) NPK3, (5) NPK4, (6) the farmyard manure (FYM), (7) FYM + NPK1, (8) FYM + NPK2, (9) FYM + NPK3, and (10) FYM + NPK4. The FYM was applied in October before moderate deep tillage $(0.2 \mathrm{~m})$ at a dose of $21 \mathrm{tha}^{-1}$. The content of nutrients in the applied FYM was approximately $105 \mathrm{~kg}, 39 \mathrm{~kg}$, and $124 \mathrm{~kg}$ of N, P, and $\mathrm{K} \mathrm{ha}^{-1}$, respectively. The doses of mineral $\mathrm{N}, \mathrm{P}$, and $\mathrm{K}$ are shown in Table 1.

Table 1. Doses of applied N, P, and K in the analysed fertilizer treatments.

\begin{tabular}{|c|c|c|c|}
\hline Fertilizer Treatment & $\mathbf{N}(\mathbf{k g ~ h a - 1 )}$ & $P\left(k_{g ~ h a-1)}\right.$ & $\mathrm{K}\left(\mathrm{kg} \mathrm{ha}^{-1}\right)$ \\
\hline NPK1 & 80 & 64 & 150 \\
\hline NPK2 & 120 & 64 & 150 \\
\hline NPK3 & 160 & 80 & 200 \\
\hline NPK4 & 200 & 80 & 200 \\
\hline FYM + NPK1 & $(105)+80$ & $(39)+64$ & $(124)+150$ \\
\hline FYM + NPK2 & $(105)+120$ & $(39)+64$ & $(124)+150$ \\
\hline $\mathrm{FYM}+\mathrm{NPK} 3$ & $(105)+160$ & $(39)+80$ & $(124)+200$ \\
\hline FYM + NPK4 & $(105)+200$ & $(39)+80$ & $(124)+200$ \\
\hline
\end{tabular}

Note: Values in parentheses represent the expected amount of nutrients provided by the FYM.

Mineral $\mathrm{N}$ was applied as lime ammonium nitrate $(27 \% \mathrm{~N})$, mineral $\mathrm{P}$ as the superphosphate $(8.3 \% \mathrm{P})$, and mineral $\mathrm{K}$ as potassium chloride $(49.8 \% \mathrm{~K})$. Mineral $\mathrm{P}$ and $\mathrm{K}$ fertilizers were applied in autumn and were incorporated into the soil by moderate deep tillage $(0.2 \mathrm{~m})$. Mineral $\mathrm{N}$ was applied in the spring, before the beet planting. The harvest of the sugar beet was in October. The sugar beet tops from each experimental plot were separated from the beetroots by hand trimmers and weighed in a net using a mobile digital scale. The harvest of sugar beet beetroots was done using a root crops digger. The beetroots were, then, weighted in the same way as the sugar beet tops, using the nets and mobile digital scale.

\subsection{Sugar Beet Analyses}

\subsubsection{Nitrogen and Phosphorus Content in Plant Materials}

Nitrogen and phosphorus contained in plant tissues were determined by mineralization with a mixture of sulfuric acid, hydrogen peroxide, and selenium. A portion of the analysed sample was oxidized with hydrogen peroxide in concentrated sulfuric acid. After decomposition of the hydrogen peroxide and distillation of the water, the mineralization was completed by boiling with sulfuric acid under the catalytic action of selenium. The resulting solution was analysed using a San plus System SKALAR analyser (Skalar Analytical B.V., Breda, The Netherlands).

\subsubsection{The Contents of $\mathrm{K}, \mathrm{Ca}, \mathrm{Mg}$, and $\mathrm{Na}$ in Plant Materials}

The contents of $\mathrm{K}, \mathrm{Ca}, \mathrm{Mg}$, and $\mathrm{Na}$ in plant tissues were determined by oxidation with hydrogen peroxide in a concentrated nitric acid medium in a closed system with a controlled temperature rise, using a Milestone microwave digestion system (Milestone Inc., Sorisole, Italy). The final analysis was carried out using a ICP-OES Trace Scan device (Thermo Jarrel Ash, Trace Scan, Franklin, TN, USA).

\subsubsection{Sugar Content Analysis}

Sampling and determination of sugar content were performed following the ČSN 462110 standard. Laboratory processing of whole sugar beet beetroots bean with its cleaning and subsequent mechanical processing. Beetroots were cut into slices to represent its entire profile. In this way, a sample was taken from each beetroot and further grated on a mechanical grater. The grated material was thoroughly mixed to be sufficiently 
homogeneous. From the sample, thus prepared, $26 \mathrm{~g}$ was again weighed, put into a beaker, and circumfused with the extraction solution. This was followed by heating in a water bath heated to $80^{\circ} \mathrm{C}$ for $30 \mathrm{~min}$. After this time, the samples were cooled to room temperature, filtered through a filter, and the filtrate was poured through a tube of an automatic polarimeter (Polarimeter MCP 200, Anton Paar, Graz, Austria).

\subsection{Soil Analysis}

The samples of the soil (Ap horizon, 0-30 $\mathrm{cm}$ ) were taken using a soil probe. Totally, four soil samples were taken from each experimental plot. The $\mathrm{pH}$ value was analysed potentiometrically (inoLab pH 730, WTW, Xylem Analytics, Weilheim, Germany). The content of soil organic carbon (Corg) was analysed according to [2,3]. The content of nitrogen (Ntot) was done using sulfuric acid in the heating block (Tecator, Sweden), and following the Kjeldahl method [32]. The contents of soil P, K, Ca, and Mg were analysed via the Mehlich III solution [33], followed by ICP-OES analysis (Thermo Scientific iCAP 7400 Duo, Thermo Fisher Scientific, Cambridge, UK).

\subsection{Data Analyses}

The analysis of variance (ANOVA) was used to evaluate the effect of fertilizer treatment in one season. For the evaluation of fertilizer treatment, season, and their interaction, the multivariate analysis of variance (MANOVA) was used. Both analyses were followed by Tukey's HSD post hoc test to select the treatments and seasons that differentiated significantly. To perform all analyses, we used STATISTICA 13.3 software (TIBCO Software, Palo Alto, CA, USA). The linear-plateau model was calculated using the R software ( $R$ : A language and environment for statistical computing. R Foundation for Statistical Computing, Vienna, Austria, 2020), together with the three R packages [34-36].

\section{Results}

\subsection{The Effect of Farmyard Manure (FYM) on Sugar Beet Beetroot and Top Yield}

If we compare the effect of manure application, we find that the beetroot yield in the observed period (2016-2018) was significantly affected by both the fertilization treatment (d.f. $=1, \mathrm{~F}=13.58, p<0.001$ ) and especially the weather conditions (d.f. $=2, \mathrm{~F}=73.48$, $p<0.002$ ). The effect of the interaction between the treatment and year was also significant (d.f. $=2, \mathrm{~F}=4.29 ; p<0.03$ ). The conditions of the year had the highest impact on beetroot yield $(80 \%)$, followed by the fertilizer treatment $(15 \%)$, and their interaction $(5 \%)$.

The application of the FYM provided comparable results as the control. Significantly higher yields were recorded only in 2016 (Table 2). The average beetroot yield was $52.9 \mathrm{tha}^{-1}$ in the control, and $61.2 \mathrm{t} \mathrm{ha}^{-1}$ in the FYM treatment (2016-2018, Table 2). Comparing the years, the average yield was $66.2 \mathrm{t} \mathrm{ha}^{-1}$ and $67.2 \mathrm{t} \mathrm{ha}^{-1}$ in 2016 and 2017, respectively (without a statistical difference), while the significantly lower yield was recorded in 2018 $\left(37.8 \mathrm{t} \mathrm{ha}^{-1}\right)$ (Table 2$)$.

Table 2. The beetroot and top yield as affected by the fertilizer treatment (control and farmyard manure (FYM)) and year (2016-2018).

\begin{tabular}{|c|c|c|c|c|c|c|c|c|}
\hline & \multicolumn{3}{|c|}{ Beetroot Yield ( $t \mathrm{ha}^{-1}$ ) } & \multicolumn{5}{|c|}{ Top Yield (t ha $\left.{ }^{-1}\right)$} \\
\hline & 2016 & 2017 & 2018 & $\bar{X}$ & 2016 & 2017 & 2018 & $\bar{x}$ \\
\hline Control & $57.4 \pm 4.3 \mathrm{~A}$ & $65.7 \pm 2.0 \mathrm{~A}$ & $35.6 \pm 4.0 \mathrm{~A}$ & $52.9 \pm 4.3 \mathrm{~A}$ & $20.4 \pm 1.5 \mathrm{~A}$ & $22.8 \pm 0.6 \mathrm{~A}$ & $9.0 \pm 0.1 \mathrm{~A}$ & $17.4 \pm 1.9 \mathrm{~A}$ \\
\hline FYM & $75.0 \pm 1.1 \mathrm{~B}$ & $68.7 \pm 1.0 \mathrm{~A}$ & $39.9 \pm 2.3 \mathrm{~A}$ & $61.2 \pm 4.7 \mathrm{~B}$ & $23.8 \pm 0.6 \mathrm{~A}$ & $24.8 \pm 1.7 \mathrm{~A}$ & $9.6 \pm 0.9 \mathrm{~A}$ & $19.4 \pm 2.2 \mathrm{~B}$ \\
\hline & $66.2 \pm 3.9 \mathrm{Bb}$ & $67.2 \pm 1.2 b$ & $37.8 \pm 2.3 a$ & & $22.1 \pm 1.0 \mathrm{~b}$ & $23.8 \pm 0.9 b$ & $9.3 \pm 0.4 a$ & \\
\hline
\end{tabular}

Note: The mean values with the standard error of the mean followed by the same letter (small letters "a", horizontally; and big letters " $\mathrm{A}$ ", vertically) are not significantly different $(p, 0.05)$.

In the individual years, the top yield was not affected by the FYM application (Table 2). However, for the entire evaluated period (2016-2018), the differences among the compared treatments (d.f. $=1, \mathrm{~F}=5.5, p<0.03$ ) and years (d.f. $=2, \mathrm{~F}=113.0, p<0.001$ ) were significant. 
While the effect of the year was $95 \%$, the effect of fertilization was only $5 \%$. As in the case of beetroots, this means that the differences between the compared fertilization treatments were very low, while the fluctuation between the years was very high (caused mainly by the severe drought in 2018). The average top yield was $17.4 \mathrm{t} \mathrm{ha}^{-1}$ in the control, while it was $19.4 \mathrm{t} \mathrm{ha}^{-1}$ in the FYM treatment. Comparing the years, the highest yields were recorded in $2017\left(23.8 \mathrm{tha}^{-1}\right)$, followed by $2016\left(22.1 \mathrm{tha}^{-1}\right)$, and $2018\left(9.3 \mathrm{t} \mathrm{ha}^{-1}\right)$ (Table 2).

\subsection{The Effect of Mineral NPK on Sugar Beet Beetroot and Top Yield}

If we compare the entire period (2016-2018), the application of mineral NPK fertilizers generally increased the beetroot yield significantly (Table 3). According to MANOVA, the beetroot yield was mainly affected by the year (d.f. $=2, \mathrm{~F}=146.3, p<0.0001,92 \%$ ), showing a very high fluctuation among the years. The highest average yield was recorded in $2017\left(72.2 \mathrm{t} \mathrm{ha}^{-1}\right)$, followed by $2016\left(68.2 \mathrm{tha}^{-1}\right)$, and $2018\left(44.4 \mathrm{tha}^{-1}\right)$. The effect of the fertilizer treatment was also significant (d.f. $=4, \mathrm{~F}=11.4, p<0.001$ ), but the only significant difference was recorded between the control and NPK treatments. However, no significant differences among NPK1-4 treatments were recorded over the entire period (Table 3). The average beetroot yield was $52.9 \mathrm{tha}^{-1}$ (control), $61.3 \mathrm{tha}^{-1}$ (NPK1), $62.7 \mathrm{t} \mathrm{ha}^{-1}$ (NPK3), $63.3 \mathrm{t} \mathrm{ha}^{-1}$ (NPK2), and $67.7 \mathrm{t} \mathrm{ha}^{-1}$ (NPK4). When only NPK treatments were considered, yield response to $\mathrm{N}$ rates across three years plateaued at $112 \mathrm{~kg} \mathrm{ha}^{-1} \mathrm{~N}$ with a corresponding beetroot yield of $66 \mathrm{t} \mathrm{ha}^{-1}$ (Figure 2, left).

Table 3. The beetroot and top yield as affected by the fertilizer treatment (control, NPK1-4) and years (2016-2018).

\begin{tabular}{|c|c|c|c|c|c|c|c|c|}
\hline & \multicolumn{3}{|c|}{ Beetroot Yield ( $t \mathrm{ha}^{-1}$ ) } & \multicolumn{5}{|c|}{ Top Yield (t ha-1) } \\
\hline & 2016 & 2017 & 2018 & $\overline{\mathbf{X}}$ & 2016 & 2017 & 2018 & $\overline{\mathbf{X}}$ \\
\hline Control & $57.4 \pm 4.3 \mathrm{~A}$ & $65.7 \pm 2.0 \mathrm{~A}$ & $35.6 \pm 4.0 \mathrm{~A}$ & $52.9 \pm 4.3 \mathrm{~A}$ & $20.4 \pm 1.5 \mathrm{~A}$ & $22.8 \pm 0.6 \mathrm{~A}$ & $9.0 \pm 0.1 \mathrm{~A}$ & $17.4 \pm 1.9 \mathrm{~A}$ \\
\hline NPK1 & $70.3 \pm 1.3 \mathrm{AB}$ & $72.9 \pm 3.1 \mathrm{~A}$ & $40.6 \pm 1.9 \mathrm{AB}$ & $61.3 \pm 4.6 \mathrm{~B}$ & $27.8 \pm 1.3 \mathrm{~B}$ & $28.2 \pm 0.7 \mathrm{~B}$ & $11.8 \pm 0.6 \mathrm{~B}$ & $22.6 \pm 2.3 \mathrm{~B}$ \\
\hline NPK2 & $70.7 \pm 3.8 \mathrm{AB}$ & $73.5 \pm 2.5 \mathrm{~A}$ & $45.7 \pm 0.7 \mathrm{ABC}$ & $63.3 \pm 4.0 \mathrm{~B}$ & $29.3 \pm 1.5 B$ & $28.8 \pm 1.1 \mathrm{~B}$ & $13.0 \pm 0.5 \mathrm{~B}$ & $23.7 \pm 2.4 \mathrm{~B}$ \\
\hline NPK3 & $68.3 \pm 2.7 \mathrm{AB}$ & $73.8 \pm 2.3 \mathrm{~A}$ & $46.1 \pm 0.8 \mathrm{BC}$ & $62.7 \pm 3.8 \mathrm{~B}$ & $32.6 \pm 1.3 \mathrm{~B}$ & $30.5 \pm 1.3 \mathrm{BC}$ & $12.0 \pm 0.4 \mathrm{~B}$ & $25.0 \pm 2.8 \mathrm{BC}$ \\
\hline NPK4 & $74.5 \pm 4.3 \mathrm{~B}$ & $75.0 \pm 2.0 \mathrm{~A}$ & $53.8 \pm 2.6 \mathrm{C}$ & $67.7 \pm 3.4 \mathrm{~B}$ & $31.4 \pm 0.7 \mathrm{~B}$ & $35.1 \pm 1.9 \mathrm{C}$ & $13.8 \pm 0.6 \mathrm{~B}$ & $26.8 \pm 2.9 C$ \\
\hline & $68.2 \pm 1.9 b$ & $72.2 \pm 1.2 b$ & $44.4 \pm 1.7 \mathrm{a}$ & & $28.3 \pm 1.1 b$ & $29.1 \pm 1.0 b$ & $11.9 \pm 0.4 \mathrm{a}$ & \\
\hline
\end{tabular}

Note: The mean values with the standard error of the mean followed by the same letter ( small letters "a", horizontally and big letters "A", vertically) are not significantly different $(p, 0.05)$.
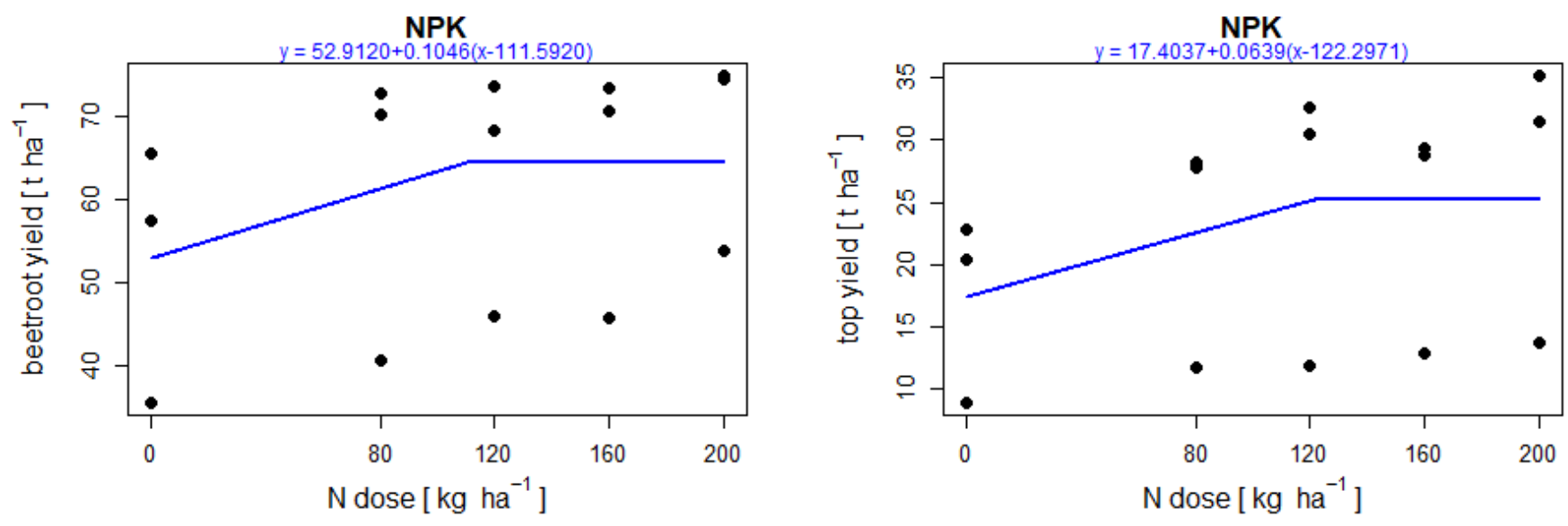

Figure 2. Means (black dots) of sugar beet beetroot yield (left) and top yield (right) at different N rates of NPK treatments in 2016, 2017, and 2018 combined and their linear-plateau regression (blue line).

In the case of the sugar beet top yield, the effect of the year (d.f. $=2, F=425.9$, $p<0.0001$ ), fertilizer treatments (d.f. $=4, \mathrm{~F}=34.3, p<0.001$ ), and their interactions (d.f. $=8$, $\mathrm{F}=3.8, p<0.002)$ was significant. The lowest average top yield over the evaluated period was provided by the control treatment $\left(17.4 \mathrm{tha}^{-1}\right)$. Significantly higher top yields were 
recorded in NPK treatments, with the highest top yield in the NPK4 treatment $\left(26.8 \mathrm{tha}^{-1}\right)$ (Table 3). The year again had the greatest impact on the top yield (92\%), followed by the fertilization treatment (7\%). Comparable top yields were recorded in the years 2016 (28.3 $\mathrm{t} \mathrm{ha}^{-1}$ ) and 2017 (29.1 $\left.\mathrm{t} \mathrm{ha}^{-1}\right)$, while a significantly lower top yield was recorded in the dry year 2018 (11.9 $\mathrm{t} \mathrm{ha}^{-1}$ ) (Table 3). According to the linear-plateau model, the mean top yield response to $\mathrm{N}$ rates across three years plateaued at $122 \mathrm{~kg} \mathrm{ha}^{-1} \mathrm{~N}$, with a corresponding top yield of $25 \mathrm{t} \mathrm{ha}^{-1}$ (Figure 2, right).

\subsection{Comparison of the FYM and FYM + NPK Treatments}

Over the entire evalutated period (2016-2018), the combined application of the FYM with mineral NPK fertilizers significantly increased the beetroot yields (d.f. = 5, F = 19.6, $p<0.001$ ) (Table 4). The lowest yield was recorded in the control (52.9 $\mathrm{t} \mathrm{ha}^{-1}$ ), followed by the FYM treatment $\left(61.2 \mathrm{t} \mathrm{ha}^{-1}\right)$. The addition of mineral NPK fertilizers significantly increased the beetroot yields as compared with the control and FYM treatments (Table 4), ranging from $65.5 \mathrm{t} \mathrm{ha}^{-1}$ (FYM + NPK3) to $66.3 \mathrm{t} \mathrm{ha}^{-1}$ (FYM + NPK1). The differences among all FYM + NPK treatments were insignificant. The effect of the year was also significant (d.f. $=2, \mathrm{~F}=333.7, p<0.0001$ ), as well as the year*treatment interaction (d.f. $=10, \mathrm{~F}=2.5$, $p=0.014)$. The comparison of years indicated the same results as the previous evaluation. While in the years with relatively favourable conditions (2016 and 2017) the differences were not significant (the average yields were $71.4 \mathrm{t} \mathrm{ha}^{-1}$ in 2016 and $72.4 \mathrm{t} \mathrm{ha}^{-1}$ in 2017), the conditions of the year 2018 sharply reduced the beetroot yield to an average value of $45.1 \mathrm{t} \mathrm{ha}^{-1}$. The beetroot yield response to different rates of FYM and NPK fertilizers plateaued at $165 \mathrm{~kg} \mathrm{ha}^{-1} \mathrm{~N}$, with a corresponding beet yield $66 \mathrm{t} \mathrm{ha}^{-1}$ (Figure 3 , left).

A similar effect of mineral fertilizers was found for the top yields. The top yield was significantly affected by the year (d.f. $=2, \mathrm{~F}=493.8, p<0.0001$ ), fertilization treatment (d.f. $=5, \mathrm{~F}=41.8, p<0.0001$ ), and their interaction (d.f. $=10, \mathrm{~F}=4.5, p<0.001$ ). The lowest yields were provided by the control and FYM treatments (17.4 and $19.4 \mathrm{t} \mathrm{ha}^{-1}$, respectively) (Table 4). The addition of mineral fertilizers increased the top yields significantly, ranging from $25.2 \mathrm{t} \mathrm{ha}^{-1}$ (FYM + NPK2) to $26.9 \mathrm{t} \mathrm{ha}^{-1}$ (FYM + NPK3). The differences between the FYM + NPK treatments were insignificant. Comparing the years, dry conditions during 2018 resulted in the lowest yield of the tops $\left(12.1 \mathrm{t} \mathrm{ha}^{-1}\right)$, while significantly higher yields were recorded in 2016 and 2017 (28.8 and $29.7 \mathrm{t} \mathrm{ha}^{-1}$, respectively). According to the linear-plateau model, the response of the sugar beet tops plateaued at $181 \mathrm{~kg} \mathrm{ha}^{-1} \mathrm{~N}$, with a corresponding yield of $24 \mathrm{tha}^{-1}$ (Figure 3 , right).
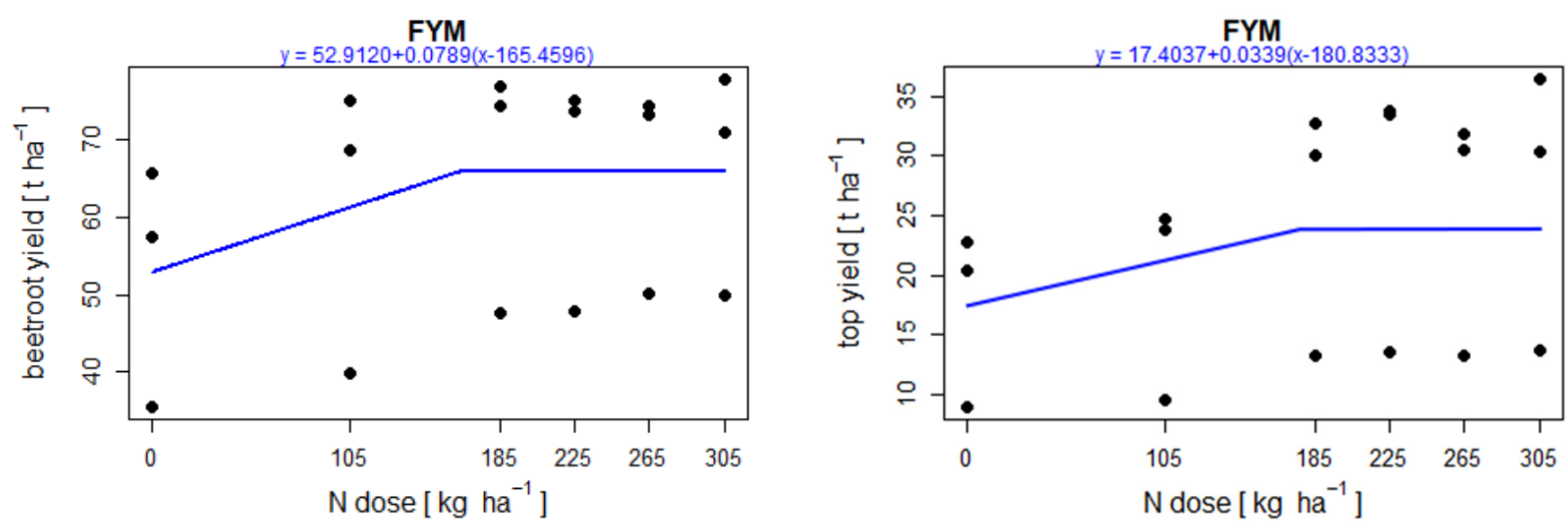

Figure 3. Means (black dots) of sugar beet beetroot yield (left) and top yield (right) at different $\mathrm{N}$ rates applied with the FYM and FYM + NPK treatments in 2016, 2017, and 2018 combined and their linear-plateau regression (blue line). 
Table 4. The beetroot and top yield as affected by the fertilizer treatment (control, FYM, FYM + NPK1-4) and years (2016-2018).

\begin{tabular}{|c|c|c|c|c|c|c|c|c|}
\hline & \multicolumn{3}{|c|}{ Beetroot Yield ( $\mathrm{t}$ ha ${ }^{-1}$ ) } & \multicolumn{5}{|c|}{ Top Yield (t ha-1) } \\
\hline & 2016 & 2017 & 2018 & $\bar{x}$ & 2016 & 2017 & 2018 & $\bar{X}$ \\
\hline Control & $57.4 \pm 4.3 \mathrm{~A}$ & $65.7 \pm 2.0 \mathrm{~A}$ & $35.6 \pm 4.0 \mathrm{~A}$ & $52.9 \pm 4.3 \mathrm{~A}$ & $20.4 \pm 1.5 \mathrm{~A}$ & $22.8 \pm 0.6 \mathrm{~A}$ & $9.0 \pm 0.1 \mathrm{~A}$ & $17.4 \pm 1.9 \mathrm{~A}$ \\
\hline FYM & $75.0 \pm 1.1 \mathrm{~B}$ & $68.7 \pm 1.0 \mathrm{AB}$ & $39.9 \pm 2.3 \mathrm{AB}$ & $61.2 \pm 4.7 \mathrm{~B}$ & $23.8 \pm 0.6 \mathrm{~A}$ & $24.8 \pm 1.7 \mathrm{AB}$ & $9.6 \pm 0.9 \mathrm{~A}$ & $19.4 \pm 2.2 \mathrm{~A}$ \\
\hline FYM+ NPK1 & $76.9 \pm 1.5 \mathrm{~B}$ & $74.4 \pm 1.7 \mathrm{BC}$ & $47.6 \pm 0.9 \mathrm{BC}$ & $66.3 \pm 4.1 C$ & $32.8 \pm 1.2 \mathrm{~B}$ & $30.1 \pm 1.2 \mathrm{BC}$ & $13.2 \pm 0.3 \mathrm{~B}$ & $25.4 \pm 2.7 \mathrm{~B}$ \\
\hline FYM + NPK2 & $73.3 \pm 1.5 \mathrm{~B}$ & $74.3 \pm 1.5 \mathrm{BC}$ & $50.0 \pm 1.4 \mathrm{C}$ & $65.9 \pm 3.5 \mathrm{BC}$ & $31.9 \pm 1.1 \mathrm{~B}$ & $30.5 \pm 1.9 \mathrm{BC}$ & $13.3 \pm 0.4 \mathrm{~B}$ & $25.2 \pm 2.6 \mathrm{~B}$ \\
\hline $\mathrm{FYM}+\mathrm{NPK} 3$ & $75.1 \pm 1.0 \mathrm{~B}$ & $73.6 \pm 0.6 \mathrm{BC}$ & $47.8 \pm 1.8 \mathrm{BC}$ & $65.5 \pm 3.8 \mathrm{BC}$ & $33.7 \pm 0.2 \mathrm{~B}$ & $33.4 \pm 0.9 \mathrm{C}$ & $13.5 \pm 0.3 \mathrm{~B}$ & $26.9 \pm 2.9 \mathrm{~B}$ \\
\hline FYM + NPK4 & $70.9 \pm 3.0 \mathrm{~B}$ & $77.8 \pm 2.1 \mathrm{C}$ & $50.0 \pm 1.3 C$ & $66.2 \pm 3.8 \mathrm{C}$ & $30.3 \pm 1.0 \mathrm{~B}$ & $36.4 \pm 2.2 \mathrm{C}$ & $13.8 \pm 0.2 \mathrm{~B}$ & $26.8 \pm 3.0 \mathrm{~B}$ \\
\hline
\end{tabular}

Note: The mean values with the standard error of the mean followed by the same letter ( small letters "a", horizontally; and big letters " $\mathrm{A}$ ", vertically) are not significantly different ( $p$, 0.05 ). 


\subsection{The Effect of Fertilization on Sugar Content (SC) and Chemical Elements Concentration}

We must admit that due to limited funds, analyses of sugar beet in reduced quantities were performed over the years 2016-2018. This means that no repeated measurements were performed from each fertilizer treatment every single year. Therefore, the results of the statistical analysis presented here represent the average results for the entire analysed period. It is, therefore, necessary to take the results with a grain of salt.

According to the statistical analysis, no significant differences were recorded between the fertilizer treatments for any analysed parameter (the SC and the concentration of $\mathrm{N}$, $\mathrm{P}, \mathrm{K}, \mathrm{Ca}, \mathrm{Mg}$, and $\mathrm{Na}$ ) of the sugar beetroots. The SC varied from $19.7 \%$ (NPK4) to $21.9 \%$ (NPK1) (Table 5). The concentration of N, P, K, Ca, Mg, and Na was not affected by the fertilizer treatment (Table 5).

Table 5. The sugar content (\%) and concentrations of $\mathrm{N}, \mathrm{P}, \mathrm{K}, \mathrm{Ca}, \mathrm{Mg}$, and $\mathrm{Na}(\%)$ in sugar beet beetroots as affected by the fertilizer treatment and over the years 2016-2018.

\begin{tabular}{|c|c|c|c|c|c|c|c|}
\hline & SC (\%) & N (\%) & $P(\%)$ & $\mathrm{K}(\%)$ & Ca (\%) & $\operatorname{Mg}(\%)$ & $\mathrm{Na}(\%)$ \\
\hline Control & $19.9 \pm 0.8$ & $0.19 \pm 0.01$ & $0.02 \pm 0.01$ & $0.16 \pm 0.03$ & $0.07 \pm 0.01$ & $0.05 \pm 0.01$ & $0.006 \pm 0.002$ \\
\hline NPK1 & $21.9 \pm 1.3$ & $0.20 \pm 0.02$ & $0.02 \pm 0.01$ & $0.17 \pm 0.03$ & $0.05 \pm 0.01$ & $0.05 \pm 0.01$ & $0.005 \pm 0.001$ \\
\hline NPK2 & $20.5 \pm 0.9$ & $0.20 \pm 0.01$ & $0.08 \pm 0.06$ & $0.17 \pm 0.02$ & $0.16 \pm 0.11$ & $0.05 \pm 0.01$ & $0.006 \pm 0.001$ \\
\hline NPK3 & $19.8 \pm 0.3$ & $0.19 \pm 0.02$ & $0.02 \pm 0.01$ & $0.16 \pm 0.03$ & $0.05 \pm 0.01$ & $0.05 \pm 0.01$ & $0.006 \pm 0.001$ \\
\hline NPK4 & $19.7 \pm 0.9$ & $0.20 \pm 0.02$ & $0.02 \pm 0.01$ & $0.18 \pm 0.04$ & $0.04 \pm 0.01$ & $0.05 \pm 0.01$ & $0.007 \pm 0.001$ \\
\hline FYM & $20.1 \pm 0.5$ & $0.19 \pm 0.01$ & $0.02 \pm 0.01$ & $0.15 \pm 0.02$ & $0.05 \pm 0.01$ & $0.05 \pm 0.01$ & $0.007 \pm 0.001$ \\
\hline FYM + NPK1 & $21.1 \pm 1.1$ & $0.20 \pm 0.02$ & $0.02 \pm 0.01$ & $0.16 \pm 0.02$ & $0.05 \pm 0.01$ & $0.05 \pm 0.01$ & $0.008 \pm 0.001$ \\
\hline FYM + NPK2 & $21.2 \pm 0.8$ & $0.22 \pm 0.02$ & $0.02 \pm 0.01$ & $0.20 \pm 0.03$ & $0.05 \pm 0.01$ & $0.05 \pm 0.01$ & $0.010 \pm 0.003$ \\
\hline FYM + NPK3 & $19.8 \pm 0.7$ & $0.20 \pm 0.02$ & $0.02 \pm 0.01$ & $0.16 \pm 0.03$ & $0.05 \pm 0.01$ & $0.05 \pm 0.01$ & $0.007 \pm 0.001$ \\
\hline FYM + NPK4 & $20.7 \pm 0.6$ & $0.21 \pm 0.01$ & $0.02 \pm 0.01$ & $0.17 \pm 0.03$ & $0.04 \pm 0.01$ & $0.05 \pm 0.01$ & $0.007 \pm 0.001$ \\
\hline
\end{tabular}

Note: The mean values without letters were not significantly different.

Similar results were recorded in the case of the sugar beet tops, where the concentrations of $\mathrm{N}, \mathrm{P}, \mathrm{K}, \mathrm{Ca}$, and $\mathrm{Mg}$ were analysed. Except for $\mathrm{P}$, the effect of the fertilizer treatment was insignificant. All results are shown in Table 6 . In the case of $P$, the mean concentration varied from $0.15 \%$ (control) to $0.23 \%$ (NPK4 and FYM + NPK1 treatments). Higher concentrations of the P were found in the FYM + NPK treatments as compared with the control, FYM, and NPK treatments (Table 6).

Table 6. The concentrations of N, P, K, Ca, and Mg in sugar beet tops as affected by the fertilizer treatment and over the years 2016-2018.

\begin{tabular}{cccccc}
\hline & N (\%) & P (\%) & K (\%) & Ca (\%) & Mg (\%) \\
\hline Control & $2.54 \pm 0.21$ & $0.15 \pm 0.01 \mathrm{~A}$ & $3.66 \pm 0.17$ & $1.38 \pm 0.12$ & $0.85 \pm 0.10$ \\
NPK1 & $2.39 \pm 0.23$ & $0.19 \pm 0.01 \mathrm{AB}$ & $4.35 \pm 0.21$ & $1.26 \pm 0.15$ & $0.84 \pm 0.10$ \\
NPK2 & $2.63 \pm 0.15$ & $0.20 \pm 0.01 \mathrm{AB}$ & $4.43 \pm 0.24$ & $1.15 \pm 0.18$ & $0.79 \pm 0.11$ \\
NPK3 & $2.67 \pm 0.17$ & $0.19 \pm 0.01 \mathrm{AB}$ & $4.11 \pm 0.11$ & $1.25 \pm 0.17$ & $0.95 \pm 0.10$ \\
NPK4 & $3.03 \pm 0.16$ & $0.23 \pm 0.02 \mathrm{~B}$ & $4.20 \pm 0.09$ & $1.14 \pm 0.17$ & $0.84 \pm 0.13$ \\
FYM & $2.51 \pm 0.22$ & $0.18 \pm 0.01 \mathrm{AB}$ & $3.36 \pm 0.56$ & $1.25 \pm 0.06$ & $0.83 \pm 0.02$ \\
FYM + NPK1 & $2.71 \pm 0.29$ & $0.23 \pm 0.03 \mathrm{~B}$ & $3.85 \pm 0.18$ & $1.04 \pm 0.11$ & $0.76 \pm 0.06$ \\
FYM + NPK2 & $2.96 \pm 0.24$ & $0.22 \pm 0.01 \mathrm{~B}$ & $4.14 \pm 0.06$ & $1.10 \pm 0.10$ & $0.82 \pm 0.06$ \\
FYM + NPK3 & $3.07 \pm 0.12$ & $0.22 \pm 0.01 \mathrm{~B}$ & $3.55 \pm 0.08$ & $1.09 \pm 0.06$ & $0.89 \pm 0.05$ \\
FYM + NPK4 & $2.89 \pm 0.11$ & $0.22 \pm 0.01 \mathrm{~B}$ & $3.94 \pm 0.19$ & $1.08 \pm 0.08$ & $0.84 \pm 0.01$ \\
\hline
\end{tabular}

Note: The mean values with the standard error of the mean followed by the same letter are not significantly different $(p, 0.05)$. Mean values without letters were not significantly different.

\subsection{The Effect of the Fertilizer Treatments on the Soil Properties}

The application of different combinations and doses of fertilizers did not affect the value of the soil $\mathrm{pH}$. The average values ranged from 6.08 (NPK3) to 6.60 (FYM). The concentration of $\mathrm{N}$ was slightly affected by the fertilizer treatment. The lowest concentrations 
were recorded in the control and FYM treatments $(0.13 \%)$, while the highest concentrations were recored in the FYM+NPK4 treatment $(0.16 \%)$. All other treatments provided results fitting within these extreme limits. In the case of soil carbon content, the distribution of the fertilizer treatments is clearer. The lowest $C$ concentration was recorded in the control treatment $(0.99 \%)$. All FYM + NPK treatments differed significantly from this value, and ranged from $1.26 \%$ to $1.35 \%$, while the FYM and all NPK treatments filled the space between the control and FYM + NPK treatments. The concentration of soil P significantly varied among the treatments with lowest concentration in the control $\left(20 \mathrm{mg} \mathrm{kg}^{-1}\right)$ and FYM (29 $\left.\mathrm{mg} \mathrm{kg}^{-1}\right)$ treatments and highest concentrations in NPK4 $\left(70 \mathrm{mg} \mathrm{kg}^{-1}\right)$ and FYM + NPK4 (93 mg kg-1) treatments. A similar pattern was recorded in the case of K (lowest concentrations were in the control and FYM treatments, while the highest concentrations were in the NPK4 and FYM + NPK2 treatments) (Table 7). The concentrations of Ca and $\mathrm{Mg}$ were not affected by the fertilizer treatment (Table 7).

Table 7. The basic soil chemical properties as affected by the fertilizer treatment and over the years 2016-2018.

\begin{tabular}{|c|c|c|c|c|c|c|c|}
\hline & $\mathrm{pH}$ & Ntot $(\%)$ & Corg (\%) & $\begin{array}{c}P \\
\left(\mathrm{mg} \mathrm{kg}^{-1}\right)\end{array}$ & $\begin{array}{c}\mathrm{K} \\
\left(\mathrm{mg} \mathrm{kg}^{-1}\right)\end{array}$ & $\begin{array}{c}\mathrm{Ca} \\
\left(\mathrm{mg} \mathrm{kg}^{-1}\right)\end{array}$ & $\begin{array}{c}\mathrm{Mg} \\
\left(\mathrm{mg} \mathrm{kg}^{-1}\right)\end{array}$ \\
\hline Control & $6.44 \pm$ & $0.13 \pm 0.01 \mathrm{~A}$ & $0.99 \pm 0.04 \mathrm{~A}$ & $20 \pm 4 \mathrm{~A}$ & $150 \pm 7 \mathrm{~A}$ & $3097 \pm 104$ & $180 \pm 9$ \\
\hline NPK1 & $6.26 \pm 0.18 \mathrm{~B}$ & $0.14 \pm 0.01 \mathrm{AB}$ & $1.10 \pm 0.03 \mathrm{AB}$ & $53 \pm 10 B C$ & $182 \pm 8 \mathrm{ABC}$ & $2813 \pm 121$ & $150 \pm 10$ \\
\hline NPK2 & $6.20 \pm 0.29 B$ & $0.14 \pm 0.01 \mathrm{AB}$ & $1.15 \pm 0.05 \mathrm{AB}$ & $59 \pm 5 C D$ & $198 \pm 11 \mathrm{ABC}$ & $2951 \pm 231$ & $149 \pm 3$ \\
\hline NPK3 & $6.08 \pm 0.08 C$ & $0.13 \pm 0.01 \mathrm{~A}$ & $1.16 \pm 0.05 \mathrm{AB}$ & $52 \pm 2 \mathrm{BC}$ & $173 \pm 14 \mathrm{AB}$ & $2790 \pm 99$ & $147 \pm 16$ \\
\hline NPK4 & $6.20 \pm 0.12 B$ & $0.14 \pm 0.01 \mathrm{AB}$ & $1.22 \pm 0.04 \mathrm{AB}$ & $70 \pm 1 \mathrm{CDE}$ & $195 \pm 10 \mathrm{ABC}$ & $2800 \pm 139$ & $141 \pm 7$ \\
\hline FYM & $6.60 \pm 0.17 \mathrm{~A}$ & $0.14 \pm 0.01 \mathrm{AB}$ & $1.19 \pm 0.05 \mathrm{AB}$ & $29 \pm 5 \mathrm{AB}$ & $166 \pm 15 \mathrm{~A}$ & $3240 \pm 214$ & $187 \pm 1$ \\
\hline FYM + NPK1 & $6.46 \pm 0.21 \mathrm{~A}$ & $0.15 \pm 0.01 \mathrm{AB}$ & $1.27 \pm 0.07 \mathrm{~B}$ & $64 \pm 1 \mathrm{CDE}$ & $199 \pm 23 \mathrm{ABC}$ & $3154 \pm 308$ & $176 \pm 15$ \\
\hline FYM + NPK2 & $6.34 \pm 0.20 \mathrm{AB}$ & $0.15 \pm 0.01 \mathrm{AB}$ & $1.31 \pm 0.10 \mathrm{~B}$ & $87 \pm 6 \mathrm{DE}$ & $246 \pm 11 C D$ & $3031 \pm 244$ & $172 \pm 10$ \\
\hline FYM + NPK3 & $6.19 \pm 0.11 \mathrm{~B}$ & $0.15 \pm 0.01 \mathrm{AB}$ & $1.26 \pm 0.02 \mathrm{AB}$ & $73 \pm 3 \mathrm{CDE}$ & $202 \pm 13 \mathrm{ABC}$ & $2891 \pm 142$ & $170 \pm 5$ \\
\hline FYM + NPK4 & $6.26 \pm 0.20 B$ & $0.16 \pm 0.01 \mathrm{~B}$ & $1.35 \pm 0.07 \mathrm{~B}$ & $93 \pm 12 E$ & $254 \pm 24 \mathrm{D}$ & $3022 \pm 129$ & $177 \pm 3$ \\
\hline
\end{tabular}

Note: The mean values with the standard error of the mean followed by the same letter are not significantly different $(p, 0.05)$. Mean values without letters were not significantly different.

\section{Discussion}

As compared with the control, statistically higher beetroot yields in the FYM treatment were recorded only in $2016\left(+17.6 \mathrm{t} \mathrm{ha}^{-1}\right)$. In the following years, the application of FYM resulted in comparable yields. If we compare the entire evaluated period (2016-2018), the application of FYM increased the average sugar beet beetroot yield by about $8 \mathrm{t} \mathrm{ha}^{-1}$. In the case of the tops, no differences between the control and the FYM treatments were recorded in individual years. A comparison of the entire analysed period showed that the average top yield was significantly higher in the FYM treatment $\left(+2.0 \mathrm{t} \mathrm{ha}^{-1}\right)$ (Table 2). As mentioned above, the mineralization of manure in the soil strongly depends on the weather and other soil parameters [20]. The years 2016 and 2017 represent seasons with relatively good (2016) and good (2017) conditions, resulting in very high yields in the control (especially in 2017, these yields are very high for the unfertilized control treatment and we assume that they are the result of exceptionally good climatic conditions during the season), and visible effect of the FYM (especially in 2016). The extremely unfavourable weather conditions in 2018 reduced beetroot yields by $43 \%$ and top yields by $69 \%$. The explanation for the higher yields in the FYM treatment lies both in the direct supply of nutrients through mineralization and the course of mineralization. According to Barłóg et al. [8], three main periods of beetroot yield formation can be distinguished, i.e., early, midseason, and final period, with $\mathrm{N}$ requirements dominating in the first two stages. The FYM is a fertilizer with a high $\mathrm{C} / \mathrm{N}$ ratio (in comparison with slurries), and contains a high amount of organic $\mathrm{N}$ that is not directly available to plants [20], therefore, FYM releases its nutrients slowly and over a longer period, covering critical periods of beet formation (if weather conditions allow it). A similar effect of FYM on sugar beet yield was published in [21]. According to their results, the yield response to different manure ratios across two years plateaued at $23 \mathrm{tha}^{-1}$, with a corresponding beet yield of $62.2 \mathrm{t} \mathrm{ha}^{-1}$. The sugar content (SC, \%) was not 
affected by the FYM application. Both treatments (control and FYM) varied from 19.9\% to $20.1 \%$. The same situation happened in the case of other chemical elements in the beetroots and tops (Tables 5 and 6), therefore, the application of the FYM provided higher yields and, consequently, a higher amount of sugar harvested from the field, without significant changes in sugar beet chemical composition. This also applies to the comparison of all other fertilization treatments (Tables 5 and 6), except P concentration in sugar beet tops (Table 6), where P concentration slightly increases in NPK4 and all FYM + NPK treatments.

Application of mineral fertilizers significantly increased beetroot and top yield (Table 3). This result is expected and is in line with other published results $[6,9,14,21]$, as $\mathrm{N}$ is the most important element for sugar beet and mineral fertilizers provide readily available $\mathrm{N}$ in precisely definable amounts. In our research, it was rather crucial to recommend an average dose of nitrogen that provided the best results during the years including both, the standard and the dry weather conditions. In the case of mineral fertilizers applied without organic manures, it is relatively simple and our results are comparable with other recommendations $[12,15,16]$, while lower than recommendations of $[13,14]$, but every experiment provides site-specific recommendations concerning soil and climate conditions of the site. In our case, a dose of $122 \mathrm{~kg} \mathrm{ha}^{-1} \mathrm{~N}$ represents a breakpoint between the linear and plateau functions of the developed model, with the corresponding beetroot yield of $66 \mathrm{tha} \mathrm{h}^{-1}$. Application of $\mathrm{N}$ above this value does not increase the beetroot yield significantly.

The combined application of FYM and mineral fertilizers (FYM + NPK treatments) had a different course each year. In years with good climatic conditions, the beetroot yield fertilized with the FYM was comparable (2016) or slightly lower (2017, only FYM + NPK4 treatment provided significantly higher yields as compared with the FYM treatment) than in the FYM + NPK treatments (Table 4). A significant difference only became apparent with the advent of drought in 2018, when treatments fertilized with FYM + NPK provided higher yields than treatments fertilized only with FYM. In years with a normal course, manure could cover the demands of beets during the season and provided very good yields. However, in the event of a drought, the efficiency of manure decreased as it responded more sensitively to unsuitable climatic conditions. The positive benefit of mineral fertilizers was also manifested in the case of the tops. The combined application of FYM and mineral fertilizers provided, on average, higher yields than the application of FYM alone. These results were predictable. For this article, it was more important to analyse the response of beetroots and tops to the dose of nutrients and to determine the recommended dose. From this point of view, it is interesting that the breaking point of the linear-plateau model occurred at the same value as in the NPK treatments, i.e., $66 \mathrm{t} \mathrm{ha}^{-1}$, but the amount of nitrogen increased to $165 \mathrm{~kg} \mathrm{ha}^{-1}$ (+53 kg ha-1 $\mathrm{N}$ as compared with the NPK treatments). The same situation occurred in the case of the beet tops, where the break occurred at a yield of $24 \mathrm{t} \mathrm{ha}^{-1}$, and at a dose of $181 \mathrm{~kg} \mathrm{ha}^{-1} \mathrm{~N}\left(+59 \mathrm{~kg} \mathrm{ha}^{-1} \mathrm{~N}\right.$ as compared with the NPK treatments). According to the data, the combined application of FYM and NPK did not bring any massive improvement in yields as compared with NPK or FYM applied alone, showing that maximum yielding potential of the sugar beet was reached under local soil-climate conditions. According to [8], the maximum yield potential of sugar beet in Europe is between 110 and $150 \mathrm{t} \mathrm{ha}^{-1}$ (calculations based on [7]), and around $80 \mathrm{t} \mathrm{ha}^{-1}$ in Poland, but the farmers' share of the actual yields is only 50 or $60 \%$ of that value.

According to the MANOVA results, both, beetroot and top yields were mainly affected by the weather conditions, while the effect of the fertilizer treatment was minor. This was mainly due to the extraordinary dry year in 2018. There is an increasing number of dry years and their frequent occurrence and weather instability, generally, are associated with the current global change in climate conditions. These extreme years should not be surprising in the coming period. The farmers in Europe are already adapting their approaches to this fact by selecting other crop varieties and species and adjusting the timing of cultivation [37]. 
A slightly different situation is found in the case of soil parameters. Application of NPK without organic manures resulted in generally lower $\mathrm{pH}$ values as compared with the control and FYM treatments (Table 7). The applications of FYM + NPK treatments resulted in between these two groups, which mean that FYM reduces the negative impact of NPK on soil $\mathrm{pH}$. The same results were published by [24,38]. By affecting the value of the soil $\mathrm{pH}$, organic manures also modify the environment for and activity of the microbial community in the soil [24], and the availability of nutrients. The concentration of soil $\mathrm{N}$ was not affected significantly by the fertilizer treatment, only high doses of applied mineral $\mathrm{N}$ (FYM + NPK4) resulted in significantly higher $\mathrm{N}$ concentration as compared with the control. In the case of $\mathrm{P}$ and $\mathrm{K}$, the highest concentrations of both elements were recorded in FYM + NPK treatments, The combination of FYM with NPK significantly increased the soil $\mathrm{C}$ content. This result is in agreement with the results published by $[24,39,40]$. On the one hand, application of mineral fertilizers without manures can decrease soil carbon content when the $C$ inputs to the soil from arable crops (including straw, roots, and post-harvest residues) are lower than the $C$ decomposed by the soil microbial community. On the other hand, organic manures contain organic matter that directly affects the physiological, chemical, and biological properties of the soil. From this point of view, the combined application of FYM and mineral fertilizers results in maintaining soil fertility and is a sustainable approach to soil care $[24,26,39]$.

\section{Conclusions}

The decisive factors determining sugar beet beetroot and top yield were weather conditions. During the years with relatively good (2016) and good (2017) conditions, the beetroot and top yield was on average $70 \mathrm{t} \mathrm{ha}^{-1}$ and $28.7 \mathrm{tha} \mathrm{h}^{-1}$, respectively. In the extraordinary dry year of 2018, the average beetroot and top yield decreased to $44 \mathrm{tha}^{-1}$ and $12 \mathrm{tha}^{-1}$, respectively.

The application of FYM at a dose of $21 \mathrm{tha}^{-1}$ significantly increased the beetroot and top yield, if we evaluate the entire period (2016-2018). In individual years, we recorded a significant difference only in the case of beetroots, in 2016. In general, the yields with FYM treatment were always higher than in the case of the non-fertilized control.

The application of mineral fertilizers significantly increased beetroot and top yield as compared with the unfertilized control. According to the results of the linear-plateau model, a suitable $\mathrm{N}$ dose is $112 \mathrm{~kg} \mathrm{ha}^{-1}$ with a corresponding yield of $66 \mathrm{t} \mathrm{ha}{ }^{-1}$. This model took into account the average yields of years including standard and unsuitable climatic conditions.

In the case of the joint application of FYM and NPK, we did not record a significant increase in yield as compared with NPK applied alone.

The sugar content and the concentration of chemical elements in the beetroots and the tops were not significantly affected by the fertilization treatment, except for slightly higher concentrations of $\mathrm{P}$ in the tops.

The application of NPK in the soil resulted in lower $\mathrm{pH}$ values than we observed in the control and FYM treatments. The combined application of FYM and NPK slightly reduced the negative impact of NPK on soil pH. The application of NPK, FYM, and especially the combination of NPK and FYM significantly increased the content of Corg, P, and K in the soil.

Author Contributions: Conceptualization, L.H., L.M., and E.K.; methodology, L.H. and E.K.; software, L.H., and K.K.; validation, L.H., L.M., and K.K.; formal analysis, L.H., and K.K.; investigation, L.H., L.M., E.K., and K.K.; resources, L.H., and E.K.; data curation, L.H., and E.K.; writing-original draft preparation, L.H.; writing—review and editing, L.H.; visualization, L.H., and K.K.; supervision, E.K.; project administration, L.H., and E.K.; funding acquisition, E.K. All authors have read and agreed to the published version of the manuscript.

Funding: This research was funded by the Ministry of Agriculture of the Czech Republic, grant number RO 0418. 
Informed Consent Statement: Informed consent was obtained from all subjects involved in the study.

Data Availability Statement: Data sharing not applicable.

Acknowledgments: We would like to thank the technicians who participated in the experiment and analyses.

Conflicts of Interest: The authors declare no conflict of interest.

\section{References}

1. Andrejčíková, M.; Macák, M.; Habán, M. Úrodový potenciál odrôd sladovníckeho jačmeňa (Hordeum vulgare L.) v pestovatel’ských podmienkach juhozápadného Slovenska. J. Cent. Eur. Agric. 2016, 17, 932-940. [CrossRef]

2. Götze, P.; Rücknagel, J.; Wensch-Dorendorf, M.; Märländer, B.; Christen, O. Crop rotation effects on yield, technological quality and yield stability of sugar beet after 45 trial years. Eur. J. Agron. 2017, 82, 50-59. [CrossRef]

3. Swędrzyńska, D.; Grześ, S. Impact of long-term tillage systems and different nitrogen fertilization on chemical and biological properties of soil and sugar beet yield. Fragm. Agron. 2017, 34, 92-106.

4. Koch, H.J.; Dieckmann, J.; Büchse, A.; Märländer, B. Yield decrease in sugar beet caused by reduced tillage and direct drilling. Eur. J. Agron. 2009, 30, 101-109. [CrossRef]

5. Laufer, D.; Koch, H.J. Growth and yield formation of sugar beet (Beta vulgaris L.) under strip tillage compared to full width tillage on silt loam soil in Central Europe. Eur. J. Agron. 2017, 82, 182-189. [CrossRef]

6. Afshar, R.K.; Nilahyane, A.; Chen, C.; He, H.; Bart Stevens, W.; Iversen, W.M. Impact of conservation tillage and nitrogen on sugarbeet yield and quality. Soil Tillage Res. 2019, 191, 216-223. [CrossRef]

7. Kenter, C.; Hoffmann, C.M.; Märländer, B. Effects of weather variables on sugar beet yield development (Beta vulgaris L.). Eur. J. Agron. 2006, 24, 62-69. [CrossRef]

8. Barłóg, P.; Grzebisz, W.; Szczepaniak, W.; Peplinski, K. Sugar beet response to balanced nitrogen fertilization with phosphorus and potassium. Part II. dynamics of beet quality. Bulg. J. Agric. Sci. 2014, 20, 1311-1318.

9. Hergert, G.W. Sugar Beet Fertilization. Sugar. Tech. 2010, 12, 256-266. [CrossRef]

10. Koch, H.J.; Laufer, D.; Nielsen, O.; Wilting, P. Nitrogen requirement of fodder and sugar beet (Beta vulgaris L.) cultivars under high-yielding conditions of northwestern Europe. Arch. Agron. Soil Sci. 2016, 62, 1222-1235. [CrossRef]

11. Zarski, J.; Kuśmierek-Tomaszewska, R.; Dudek, S. Impact of irrigation and fertigation on the yield and quality of sugar beet (Beta vulgaris L.) in a moderate climate. Agronomy 2020, 10, 166. [CrossRef]

12. Chatterjee, A.; Subedi, K.; Franzen, D.W.; Mickelson, H.; Cattanach, N. Nitrogen fertilizer optimization for sugarbeet in the Red River valley of north Dakota and Minnesota. Agron. J. 2018, 110, 1554-1560. [CrossRef]

13. DeBruyn, A.H.; O’Halloran, I.P.; Lauzon, J.D.; Van Eerd, L.L. Effect of sugarbeet density and harvest date on most profitable nitrogen rate. Agron. J. 2017, 109, 2343-2357. [CrossRef]

14. Islamgulov, D.; Alimgafarov, R.; Ismagilov, R.; Bakirova, A.; Muhametshin, A.; Enikiev, R.; Ahiyarov, B.; Ismagilov, K.; Kamilanov, A.; Nurligajnov, R. Productivity and technological features of sugar beet root crops when applying of different doses of nitrogen fertilizer under the conditions of the middle cis-ural region. Bulg. J. Agric. Sci. 2019, 25, 90-97.

15. Malnou, C.S.; Jaggard, K.W.; Sparkes, D.L. A canopy approach to nitrogen fertilizer recommendations for the sugar beet crop. Eur. J. Agron. 2006, 25, 254-263. [CrossRef]

16. Jaggard, K.W.; Qi, A.; Armstrong, M.J. A meta-analysis of sugarbeet yield responses to nitrogen fertilizer measured in England since 1980. J. Agric. Sci. 2009, 147, 287-301. [CrossRef]

17. George, H.; Hanlon, E.; Overman, A. Fertilizer Experimentation, Data Analyses, and Interpretation for Developing Fertilization Recommendations_Examples with Vegetable Crop Research 2017. Available online: https:/ / edis.ifas.ufl.edu/pdffiles/SS/SS548 00.pdf (accessed on 12 December 2020).

18. Hlisnikovský, L.; Men ík, L.; Kunzová, E. The development of winter wheat yield and quality under different fertilizer regimes and soil-climatic conditions in the Czech Republic. Agronomy 2020, 10, 1160. [CrossRef]

19. Lim, W.; Sonn, Y.; Yoon, Y. The Selection of Yield Response Model of Sugar beet ( Beta vulgaris var. Aaron ) to Nitrogen Fertilizer and Pig Manure Compost in Reclaimed Tidal Land Soil. Korean J. Soil Sci. Fertil. 2010, 43, 174-179.

20. Eghball, B.; Wienhold, B.J.; Gilley, J.E.; Eigenberg, R.A. Mineralization of manure nutrients. J. Soil Water Conserv. 2002, 57, 470-473.

21. Maharjan, B.; Hergert, G.W. Composted cattle manure as a nitrogen source for sugar beet production. Agron. J. 2019, 111, 917-923. [CrossRef]

22. Davis, J.G.; Westfall, D.G. Fertilizing Sugar Beets. Available online: https://extension.colostate.edu/topic-areas/agriculture/ fertilizing-sugar-beets-0-542/ (accessed on 8 October 2020).

23. Pişkin, A. The effect of sheep manure on yield and quality in production of organic sugar beet. Isr. J. Plant Sci. 2019, 66, 238-242. [CrossRef]

24. Du, Y.; Cui, B.; Zhang, Q.; Wang, Z.; Sun, J.; Niu, W. Effects of manure fertilizer on crop yield and soil properties in China: A meta-analysis. Catena 2020, 193. [CrossRef]

25. Li, H.; Feng, W.T.; He, X.H.; Zhu, P.; Gao, H.J.; Sun, N.; Xu, M. Gang Chemical fertilizers could be completely replaced by manure to maintain high maize yield and soil organic carbon (SOC) when SOC reaches a threshold in the Northeast China Plain. J. Integr. Agric. 2017, 16, 937-946. [CrossRef] 
26. Menšík, L.; Hlisnikovský, L.; Kunzová, E. The State of the Soil Organic Matter and Nutrients in the Long-Term Field Experiments with Application of Organic and Mineral Fertilizers in Different Soil-Climate Conditions in the View of Expecting Climate Change. In Organic Fertilizers - History, Production and Applications; IntechOpen: London, UK, 2019.

27. Ren, F.; Sun, N.; Xu, M.; Zhang, X.; Wu, L.; Xu, M. Changes in soil microbial biomass with manure application in cropping systems: A meta-analysis. Soil Tillage Res. 2019, 194, 104291. [CrossRef]

28. Tong, X.; Xu, M.; Wang, X.; Bhattacharyya, R.; Zhang, W.; Cong, R. Long-term fertilization effects on organic carbon fractions in a red soil of China. Catena 2014, 113, 251-259. [CrossRef]

29. Zavattaro, L.; Bechini, L.; Grignani, C.; van Evert, F.K.; Mallast, J.; Spiegel, H.; Sandén, T.; Pecio, A.; Giráldez Cervera, J.V.; Guzmán, G.; et al. Agronomic effects of bovine manure: A review of long-term European field experiments. Eur. J. Agron. 2017, 90, 127-138. [CrossRef]

30. Kožnarová, V.; Klabzuba, J. Doporučení WMO pro popis meteorologických, resp. klimatologických podmínek definovaného období. Rostl. Vyroba 2002, 48, 190-192.

31. FAO. World Reference Base for Soil Resources 2014. International Soil Classification System for Naming Soils and Creating Legends for Soil Maps; FAO: Rome, Italy, 2014; ISBN 9789251083697.

32. Bradstreet, R.B. Kjeldahl Method for Organic Nitrogen. Anal. Chem. 1954, 26, 185-187. [CrossRef]

33. Mehlich, A. Mehlich 3 soil test extractant: A modification of Mehlich 2 extractant. Commun. Soil Sci. Plant Anal. 1984, 15, 1409-1416. [CrossRef]

34. Arnhold, E. Easynls: Easy Nonlinear Model, R Package Version 5.0; 2017. Available online: https://cran.r-project.org/web/ packages/easynls/easynls.pdf (accessed on 11 January 2021).

35. Mangiafico, S. Rcompanion: Functions to Support Extension Education Program Evaluation, R Package Version 2.3.26; 2020. Available online: https: / / cran.r-project.org/web/packages/rcompanion/index.html (accessed on 11 January 2021).

36. Wickham, H.; Averick, M.; Bryan, J.; Chang, W.; McGowan, L.; François, R.; Grolemund, G.; Hayes, A.; Henry, L.; Hester, J.; et al. Welcome to the Tidyverse. J. Open Source Softw. 2019, 4, 1686. [CrossRef]

37. Olesen, J.E.; Trnka, M.; Kersebaum, K.C.; Skjelvåg, A.O.; Seguin, B.; Peltonen-Sainio, P.; Rossi, F.; Kozyra, J.; Micale, F. Impacts and adaptation of European crop production systems to climate change. Eur. J. Agron. 2011, 34, 96-112. [CrossRef]

38. Adekiya, A.O.; Ejue, W.S.; Olayanju, A.; Dunsin, O.; Aboyeji, C.M.; Aremu, C.; Adegbite, K.; Akinpelu, O. Different organic manure sources and NPK fertilizer on soil chemical properties, growth, yield and quality of okra. Sci. Rep. 2020, 10, 1-9. [CrossRef] [PubMed]

39. Zhang, W.; Xu, M.; Wang, B.; Wang, X. Soil organic carbon, total nitrogen and grain yields under long-term fertilizations in the upland red soil of southern China. Nutr. Cycl. Agroecosyst. 2009, 84, 59-69. [CrossRef]

40. Gai, X.; Liu, H.; Liu, J.; Zhai, L.; Yang, B.; Wu, S.; Ren, T.; Lei, Q.; Wang, H. Long-term benefits of combining chemical fertilizer and manure applications on crop yields and soil carbon and nitrogen stocks in North China Plain. Agric. Water Manag. 2018, 208, 384-392. [CrossRef] 